AÜiFD 47 (2006), sayı 2, s. 127-141

\title{
İnsanı Anlamaya Yönelik Bir Yaklaşım: Pastoral Psikoloji
}

ÖZNUR ÖZDOĞAN

DOÇ. DR., ANKARA Ü. İLAHIYAT FAKÜLTESI

e-posta: ozdogan@divinity.ankara.edu.tr

\begin{abstract}
Pastoral Psychology: As an Approach to Understand of Human. Pastoral psychology is the practical sub-area of psychology of religion. It is developed and instituonalized by Anton T. Boisenin in 1930 ths. Pastoral psychology takse place in the border of clinical psychology and spritual guidance. For this reason, pastoral psychology connects religious psychological approaches and theological approaches. In this article, it has been inquired with regard to pastoral psychology the answers for these questions; what is the pastoral psychology? How does it applied in Europe. In addition to this, it is presented one practical pastoral psychological example from Turkey.
\end{abstract}

key words: Pastoral psycholog, clinical practices, spritual guidance.

En yüce değerler insan doğasında vardır ve bu değerler keşfedilebilir. İnsanda genel anlamı ile kendini gerçekleştirme adı altında özetlenebilecek, ileriye dönük olma ya da gelişim eğiliminin varolduğunu gösteren çok sayıda anlamlı, kuramsal ve deneysel veri vardır ve bulgular birçok insan için genellenebilecek niteliktedir.*

İnsan öyle bir varoluştur ki sürekli olarak varlığın daha çok tamamlanmasına yönelir. Bu, genel olarak, iyi değerlere; dinginlik, incelik, yüreklilik, dürüstlük, sevgi, bencil olmama ve iyi olmaya yönelik bir istektir. İnsanların kendilerini geliştirdiklerinde hangi değerlere eğilim gösterdiği, hangi değerlerin peşinde koştuğu ve sağlı̆̆ını yitirdiğinde hangi değerleri yitirdiğini keşfedebiliriz: Sağlıklı olgun, gelişmiş, kendini gerçekleştirmiş olarak nitelendirdiğimiz insanların, uygun koşullarda, en iyi ve güçlü durumlarınday-

* bkz. Özdoğan, Öznur, Dindarlıkla İlgili Bazı Faktörlerin Kendini Gerçekleştirme Düzeyine Etkisi, Basılmamış Doktora Tezi Ankara, 1995. 
ken yaptığı özgür seçimler, yüksek değerler, ebedi erdemler olarak adlandırılan erdemlerle hemen hemen aynıdır. ${ }^{1}$

\section{KAVRAMSAL ÇERÇEVE}

Pastor (i) kelimesi, papaz kilise ve cemaatin dinsel sorumlusu anlamlarını taşımaktadır. Pastoral(s) kelimesi ise, kır yaşamına ait basit ev sakin bir yaşam anlamına gelmekle birlikte, cemaat üyeleri, dinsel bir topluluğun üyelerini ilgilendiren piskoposlar gibi anlamları da taşımaktadır. Diğer taraftan pastoral care (i) dini cemaat sorumlusu tarafından, cemaatine veya kilise üyelerine yapılan manevi destek, manevi yardım, tavsiyeler ve öğütler olup ayrıca, bir öğretmen veya bir eğitim yetkilisi tarafından öğrencilere yapılan manevi destek, yardım özel öğütler ve tavsiyeler anlamını taşımaktadır. ${ }^{2}$

Tarihin eski dönemlerine bakıldığında psikolojik hastalıkları tespit edip tedaviye çalışanlar papazlar, rahipler, şamanlar, medyumlar vb. manevi temsilcilerden oluşmakta idi. Özellikle akıl hastalıkları kötü metafizik güçlerin neden olduğu durumlar olarak kabul edilmekte idi (Holm, 2004: 141).

Anton Boisen klinik pastoral eğitim hareketinin öncüsü olarak kabul edilir. 1926 yılında bu alanın metoduyla ilgili yaklaşımını yazmıştır. Teolojinin Metotları ve Görevi ${ }^{3}$ adlı çalışmasında teolojinin, dinsel deneyimleri sınıflandırmak, dinsel inançlara ve bu inançların sonuçlarına dikkatle bakmak ve inançların kökenini araştırmak, anlamak konusunda en iyi bakış açısı olabileceğini söylemekte ve şöyle devam etmektedir: Dinsel deneyimlerin en üst seviyesi, yüksek bir birlik anlayışıdır. Bu noktada Yaratıcı ile iletişim ve tüm insanlığın refahı için hakiki bir merhamet duygusu oluşur.

Boisen insanın arınması için, kendi kendine kalmasını, Yaratıcıyla iletişimini tekrar inşa etmesini, O'na daha da yakınlaşmasını ve hiç zaman geçirmeden affetme deneyimini yaşamasını önermektedir (Boisen, 1936, 306).

Arınmanın hem bireysel hem de sosyal bir olay olduğunu evrensel bir bütünleşmeyle gerçekleşebileceğini söylemektedir (Boisen, 1936, 293). Boisen dünyadaki psikolojik sorunların kaynağının bencillik olduğunu vurgulamakta ve şöyle devam etmektedir. İnsan verme konusunda yarış içinde olmalıdır (Boisen, 1936, 289). Boisen bireyleri anlamak için bireyin gelişimine ve yaşamına bakılmasını, insanın gerçek kişiliğini kazanması ve devam ettirebilmesi için "nasıl bir toplum" oluşturmamız konusunda derin çalışmalar yapılmasını önermektedir (Boisen, 1936, 290).

Pastoral psikoloji, manevi rehberlik ve klinik psikoloji arasındaki sınır bölgede etkinlik gösteren din psikolojisine ait alanlardan birisidir. Bu açı-

1 Maslow, 2001, 165-181.

2 Longman- Metro, Büyük İngilizce Türkçe Sözlük: 1079-80 


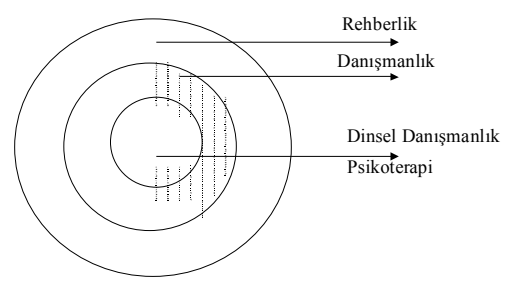

dan pastoral psikoloji, din psikolojisi yaklaşımları ile teolojik yaklaşımları birbirine bağlar. ( Holm, 2004: 152, bkz. Estadt, 1983, 4).

Rehberlik kavramı, danışmanlık ve psikoterapiyi içine alan şemsiye bir kavramdır. Dinsel danışmanlık, danışmanlığın bir alt dalı olarak görülebilir (Ok, 1997).

Pastoral Psikoloji dergisinde yayınlanmış bir makalede Pentekostal Kilisesi tarafından pastoral danışmanlı çalışmalar hakkında bilgi verilmektedir. Bu çalışmada pastoral danışmanın, danışanlar ve öğrenciler için yönlendirici ve faydalı bir süreç olduğu vurgulanmaktadır (Belcher, 2004: 97). Ayrıca Belcher, pastoral danışmanın ruhsal bir serüven, süreç ve keşif olduğunu söylemektedir.

Browning $(1993,12)$ "pastoral danışmanın ruhsal / zihinsel bir tedavi için teoloji ve psikoloji de kullanılan disiplinler arası bir alan olduğunu belirtir. Ayrıca bir çok araştırmacı pastoral danışmanın önemine dikkat çekerek pastoral danışmanların, danışanlarının ruhsal serüvenlerine yardımcı olduğunu belirtir (Eliason, Hanley \& Leventis, 2001, 78).

\section{PASTORAL UYGULAMALARIN IÇERIĞi}

Günümüzde pastoral danışmanlık sadece Hristiyan ve az da olsa Yahudi inanışında yer almaktadır. Ancak bu tür bir danışmanlığın diğer dini inanışlarda yer alabileceği söylenebilir.

Rollins, pastoral psikolojinin 1991 yılından buyana hızını artırarak gelişmekte olan bir alan olduğunu belirtmektedir (Rollins, 2002: 101).

Pastoral danışma genellikle dinsel kurumlarda papazların çalıştıkları kiliselerde/kurumlarda uygulanır. Genellikle bu tip ‘danışma'nın işlevleri ruhsal rehberlik veya kişilerin günah çıkarması şeklindedir. Pastoral danışma dinsel ve ruhsal problemlerin çözümünde kullanılan bir çeşit danışma sürecidir. Kimi zaman dinsel sorunlar, kişilik sorunlarına ve sosyal sorunlara neden olabilmektedir.

Pastoral danışmanlar, danışanlarına geniş bir yelpazede yaklaşırlar ve bütün karmaşası içinde insanın gizemini incelemeye girişirler. Onların içsel süreçleriyle, diğer insanlarla ilişkilerindeki başarıları ve başarısızlıkları ile ilgile- 
nirler. Aynı zamanda onların hayattaki amaçlarıyla buluşmalarını etkileyecek potansiyelleriyle de ilgilenirler. Sayısız düşünce okullarının yaklaşımlarından yararlanmakla birlikte, pastoral danışmanlıkta, danışanların aşkın arzuları ve duygularıyla ilgilenilmektedir. Dini fikirler ve deneyimler, kritiği yapılmaktan çok, danışmanlık teorisi ve pratiğine farklı bir boyut katmak ve örnekler vermek için kullanılmıştır. "Ağır ruhsal rahatsızlıklarla seyrek olarak ilgilenir ve bunların tedavilerini bu alanda uzmanlaşmış terapistlere ve psikiyatrlara bırakır. Bu alan her şeyden önce psikojenik/ruhsal tepkiler (yas, depresyon) ve genel olarak hayat görüşüyle ilgili soruları konu edinir." (Holm, 2004, 152).

Pastoral danışmada 3 yaklaşım önemlidir.

1- 'Hasta'nın anlattığı,

2- Danışman'ın anlattı̆̆

3- Sorunun manevi ve dinsel boyutu .

Pastoral danışmanlıkta ilişkinin bu 3 boyutu da irdelenmelidir ki daha iyi hizmet verilebilsin. Sorunun manevi ve dinsel boyutu çözüm açısından büyük önem taşır: Maneviyat yaşamsal ve cesaret veren bir enerjidir. Bütün insanların içsel ve özgün olarak ortaya koyduğu kapasite ve yönelimdir. Maneviyat, insan ruhunun, kendine ve başkalarına mutluluk veren sevgi, şefkat, sabır, hoşgörü, affetme, uyum duygusu ve sorumluluk nitelikleriyle iletişim kurmasıdır. Maneviyat doğuştan bir insan yeteneğidir. Sadece yaşamsal gücümüz değil, bu yaşamsal gücü deneyimlememizdir. Her ne kadar bu gücü yaşamak, deneyimlemek bizim bir parçamız olsa da, aynı zamanda bizi aşmaktadır. $\mathrm{O}$ bizi doğaya ve hayatın kaynağına bağlar. Maneviyatı yaşamak çeşitli hayat deneyimleriyle baş etmemize yardımcı olur (Frame, 2003, 2-3).

İnsanın temel ihtiyaçları yanında ruhsal ve manevi ihtiyaçları da vardır. Bunlar arasında inanma, bağlanma, sadık olma, dayanma, güvenme, korunma, dürüstlük, iyilik, doğruluk, adalete sahip olma vb. ihtiyaçları görmemek mümkün değildir (Yavuz, 1998, 80; 2003, 39). Bu ruhsal yönelimler bireyi, bilgiye, sevgiye, anlama, umuda, aşkınlığa, bağlanmaya ve şefkate ulaştırır. Peker, insanın kendi maddi ve manevi varlığı ile ilgili duygularının benlik duygularını oluşturduğunu, söyleyerek, benliği şöyle tanımlamaktadır; "insanın kendi kendine dışarıdan, başka bir kimse gibi bakarak "ne olduğu, nasıl hareket ettiği, değer yargılarının, iyi ve kötü taraflarının neler olduğu, neleri yapabileceği, arzu ve ideallerinin neler olduğu, nasıl olması gerektiği" şeklindeki sorulara kendisinin verdiği cevaptır." (Peker, 2003, 104). Maneviyat benlik duygusunu geliştirir, insanın değer sistemini oluşturur, gelişme kapasitesini, büyüme ve yaratıcılık potansiyelini güçlendirir. İnsanların benimseyip geliştirdikleri dini değer ve normları ile şahsiyet özellikleri arasında denge ve uyum sağlama gayreti söz konusudur. (Uysal, 1996, 
133,134). Din bir değer kaynağı ve yaşantısı, bir davranış ve uyum tarzı olarak , insan kişiliğinin ve karakterinin en derin yapıcı unsurudur (Ayhan, Hökelekli ve diğerleri, 2004, 17). Din acıları öğrenmeye, düşmanlığı işbirliğine, kayıtsızlığı sevgiye dönüştürür. Derin bir bütünlük duygusu, bağlanmak ve sonsuza kendini açmaktır.

Allport, Birey ve Dini ${ }^{4}$ adlı kitabında din ve terapinin kişilikteki düzen ve bütünlük ihtiyacı konusunda 1srarcı olmaları açısından benzeştiğini söylemektedir. Her iki yaklaşım da sağlıklı bir zihin için, duyguların hiyerarşik bir yapı gerektirdiğini, temel bir yönlendirici duygunun baskın olması gerektiğini kabul ederler.

Ona göre, bazı psikiyatrlar bazı hastalarına kendilerinden daha hasta olan kişilerle birlikte olmayı ve onlara yardım etmeyi tavsiye ederler. Psikiyatrlar böyle faaliyetlerin hastanın kendine acıma, içerleme, gücenme ile zararlı bir şekilde harcadıkları enerjilerini tekrar kazanmalarında önemli etkisinin olduğunu kabul ederler. Psikiyatrlar bu yöntemi dindeki yardımseverlik gibi erdemler nedeniyle değil, hastaların bozulmuş kişiliklerinin onarılmasına katkısı nedeniyle önerirler. Fakat din alanında çalışan insanlar bu onarılmanın tesadüfi olmadığını, yardım etmekten vb. kaynaklandığını söylerler. Sevgi, kıyaslanamayacak derecede önemli bir psikoterapik sağllk verici değerken, profesyonel psikiyatrinin kendi kendine oluşturamadığı, odaklanmadığ rapinin içinde köklendiği psikoloji bilimi, insanın sevgiyle bağlanma isteği konusunda çok az şey söylemiştir. İngiliz psikiyatr Dr. Suttie, modern bilimin şefkatten, sevgiden kaçışta olduğunu ve böylece yakın, şefkat dolu ilişkileri destekleyen dine karşı antitez ortaya koyduğunu belirtmektedir. Allport, bu kaçışın temel sebebinin bilimin analitik yapısından kaynaklandığını düşünmektedir. Ayrıca dinin, insan doğasının sevgiye olan ihtiyacına izin vermesi noktasında psikoterapiden daha ileri bir noktada olduğunu söylemektedir. Fakat sevginin yaşanmasına gelince, bu konuyla ilgili dinsel değerlerin uygulanması noktasında yıllarca süren başarısızlıkla karşı karşıyayız. Manevi danışman ve psikiyatr arasındaki ilişkiye bakıldığında, manevi danışmanlar temel inançlar, değerler ve hayatı değerlendirmede daha iyidirler. Manevi danışmanın zihinsel hastalıklardan korunma ve iyileşmede kaçınılmaz bir rolü vardır. Onun rolü psikanalistler için ödül olarak algılanabilir. Modern psikoterapik teknikler tıbbi yönelime sahiptir, bunun yanında din alanında çalışan danışmanlık konusunda özel yetişmiş insanlara yer verilmelidir.

3 The Task and Methods of Theology 
Pastoral-psikiyatri grup çalışması kavramı hızla büyüyen bir yönelimdir. İlişkinin akıcı devam etmesi için, birçok grup çalışmasında olduğu gibi, grup üyelerinden birbirlerine göre daha uyumlu olması gerekmektedir (Allport, 1950, 88-97).

Dinin ruh sağlığı açısından en önemli katkısı, ortaya koyduğu değerler ve dünya hayatına ilişkin olarak getirdiği açıklamalar aracılığıyla insan yaşamına kazandırdığı anlamdır. Aynı zamanda insanlar arası ilişkileri sağlıklı bir biçimde düzenleyerek, tarihle ve diğer insanlarla olan bağı aydınlatan din, insanoğlunun kaybetmiş olduğu gerçek kimliğine yeniden kavuşmas1na yardımcı olur (Yaparel, 23-24).

Pastoral danışmanlık kendi karakterini ararken genel anlamda danışmanlık alanına önemli bir hizmet verdiğini göstermektedir. Din de insanların çoğunluğunun hayatında yer alan bir konu olduğuna göre pastoral danışmanlar bireylerin hayatlarının önemli bir parçası olan dinden yararlanarak fakat bunun yanı sıra psikolojiyle ilgili teorik bilgileri de yadsımadan ve bunları da dini bilgilerine katarak danışanlarına daha iyi hizmet verme yolundadırlar. Dolayısıyla pastoral danışmanlar konuyu sadece dinsel açıdan görmemekte, ancak dinin de insan hayatının önemli bir parçası olduğunu bilerek ve psikoloji alanında ki gelişmeleri takip ederek hizmet vermektedirler.

\section{PASTORAL DANIŞMADA AVRUPADAKI UYGULAMALAR}

Teorik çerçeveye ek olarak, 2006 yılında İsviçre, Avusturya ve Almanya'da çeşitli hastanelerde çalışmalar gerçekleştirildi: Hastanelerdeki pastoral danışma merkezlerindeki faaliyetler araştırıldı. Hastanelerde görev yapan din adamlarıyla, hastanedeki görevleri ile ilgili görüşmeler yapıldı.

\section{Araştırma I}

Zürih St. Gallen Kanton hastanesindeki çalışmalar

Hastane kapsamında kilise hizmetleri verilmektedir. Hastanenin yanında görüşme odalarının ve Protestan ve Katolik ibadet yerlerinin bulunduğu bir bina yer almaktadır. Din adamları ölüme yakın hastaya dua yaptırmaktadırlar. Hastalar veya yakınları randevu almaktadırlar. Hareket edemeyecek hastalar için din adamlarına tam yetki veriliyor.

Hastanede Protestan din adamı olarak çalışan Susanne Weber ile görüşme: 24 Ağustos 2006

"Kanuni olarak ölülere kilisenin hizmet etmesi gerekmektedir. Cenazenin kiliseye getirilmesi ve inançlara göre ölülere değişik uygulamalar vardır. 
2 haftalık kurstan sonra burada göreve başladık. İntihar girişiminde bulunanlarla da görüşüyoruz. Hasta isterse görüşebiliriz. Randevu alanlarla görüşüyoruz. Birlikte dua ediyoruz, bağışlama çalışmaları yapıyoruz: Günahlarını itiraf ediyorlar. Mesela eşini aldattığını itiraf eder; suçluluk duygularına ilişkin konuşuyoruz. Ne olduğunu yargılamaksızın konuşmalar yapıyoruz. Yaşadıklarımızı kabullenme ve sabır üzerine konuşuyoruz. Hasta yakınlarıyla da görüşüyoruz. Katoliklerde kişi öldükten sonra işlediği günah kadar kiliseye para veriliyor."

Zürih St. Gallen Kanton hastanesi Manevi Bakım Yönergesinde şu bilgiler yer almaktadır:

\section{Biz Kimiz}

"Hastanede manevi bakım konusunda" ihtisas yapmış, Protestan ve Katolik yerel kiliseye bağlı ilahiyatçılarız. Kanton hastanesi diğer çalışanlarıyla hastalarımızın şifa bulması için birlikte çalışmalar yapıyoruz. Ökümeniklik ruhuna hizmet ediyoruz. (Protestan ve Katolik Papazlar Resmi Dairesi).

\section{Hizmetler}

Hastanemizin her biriminde her iki mezhepten de görevliler bulunmaktadır. Hastanenin acil ve özel bölümleri içinde farklı uygulamalar vardır. Biz hastalarla ve hasta sahipleriyle karşlıklı görüşüp konuşuyoruz. Bizimle görüşmek için krize müdahale, düğün ve cenazelere katılım ve daha özel dinsel ihtiyaçlarınızda arayabilirsiniz; Dua, İncil okuma, toplu olarak ya da akşam yemeklerinde, takdis etmek, hastaya dua etme ya da günah çıkarmak gibi. Bize haftanın her günü her saat 111 numaralı telefondan ulaşılabiliriz. Hastane çalışanları da benzeri sorunlarda bize baş vurabilirler. $\mathrm{Bu}$ konudaki bilgilerini de gizli tutarı.Biz hastanenin her iki ibadethanesinde de hastalarımıza, hastane çalışanlarına ve aynı zamanda dışarıdan gelen misafirlere açık, düzenli ayinler düzenlemekteyiz. Pazar ayinlerinde dışardan gelenler için fahri ulaşım birimimiz mevcuttur. Katolik ibadethanemiz tam gün hizmete açıktır.

\section{Diğer Çalışma Alanları}

Aynı zamanda biz diğer mezheplere ya da dinlere ait yabancı dil konuşan hastaların, ait oldukları inanç gruplarıyla bağlantı kurmalarını sağlıyoruz. Değişik çalışma grupları ve komisyonlarla da işbirliği içindeyiz. Biz bu hastanenin eğitim ve gelişim görevine dahiliz. Biz aynı zamanda ahlaki ve manevi sorulara yönelik halka açık kurslar ve seminerler düzenliyoruz. Aynı 
zamanda hastanedeki benzeri sorunlarla ilgili internet adresimiz www.spitalseelsorge-sg.ch Tekliflerinize ve yeni fikirlerinize açı̆̆ız.

\section{Hastanedeki manevi bakımdan biz ne anlıyoruz?}

Hastanede yatmak her insan için özel bir durumdur. Oradaki günlük yaşamın tarzı bizi bocalamaya sürüklemektedir: Bağımlılıklar, alışkanlıklar hastane yaşamını şekillendirir. İnsanda güvensizlikler ve korkular ortaya çımaya başlar. Hayat hikayesindeki eski deneyimler ve sorular ortaya çıkarlar.

Bu durumda biz din adamları konuşan olarak, iletişim kurarak hizmet vermekteyiz. Buna zaman ayırmaktayız. Hastaların arzu ettiği konulara değinmekteyiz. Hastalarımız böylece duygularını ve yaşadıkları deneyimleri dile getirme fırsatı bulurlar. Konuşma esnasında hastamız kendi durumunun ve kendine düşen görevin farkına varır. Hastayı kendi ruhsal dünyasını tanıyıp, inanç dünyasını biçimlendirmesi için destekleriz. Böylece kriz durumlarında hastalar ve onların yakınları birlikte hareket etmeyi öğrenirler.

Hristiyan geleneğinden gelen yöntemleri -dua, takdis ve ritüeller gibibizler konuşmacı olarak derinlik içinde ve sınırlarını belirleyerek etkili hale getiriyoruz.

Bizler bu buluşmalarda yaşamı paylaşma ve inancı güçlendirme arzusundayız. Sevinç ve ümit, üzüntü ve korku Tanrı' ya giden yolumuzun bir parçasıdır.

Bu bağlamda kendimizi başka inanç gruplarından ve dinlerden olan insanlara bağlı hissediyoruz. Onları da samimiyet, sorumluluk bilinci ve anlayışla karşıllyoruz.

Manevi destek terapisinde konuşma, İncil okuma, dua, yemekler, toplantılar, günah çıkarma, takdis gibi faaliyetlerle uzmanlar hizmet veriyor.

Zürih St. Gallen Kanton hastanesinde işitme engelli veya işitme kaybı olanlar için danışmanlık ve Manevi Bakım hizmetleri sunulmaktadır. Bu tür sorunları olan kişiler ve onların aileleri için şunlar yapılmaktadır:

- Kişisel veya mesleki gelişim, yaşadıkları kriz durumlarında yanınızda olup, beraber hareket etmek

- Ailelere psikolojik danışmanlık

- Psikoterapi

- Manevi bakım

Ruhsal sorunları olanlar da yararlanabilirler.

Araştırma II

Avusturya'nın Dornbirn şehrinde Kanton hastanesi ile yaşlı ve güçsüzler yurdundaki çalışmalar 
Kanton hastanesinde bir görüşme odası ve Katolikler ve Protestanlar için ibadet yerleri var. Din görevlisi ile yapılan görüşmede, durumu ciddi olan hastalara gittiğini ve dua ettiğini, günah çıkardıklarını söyledi. Pazar ayinlerine hastaların ve yakınlarının katıldığını, ibadet yerlerinin 24 saat açık olduğunu anlattı ve beni yakınlardaki yaşlı ve güçsüzler yurduna yönlendirdi.

Yaşlı ve güçsüzler yurdu doğayla iç içe, sakin, huzurlu bir ortam. Yaşlılar yemek yerken onlarla konuşma gerçekleştirildi. Dua etmenin onlara çok iyi geldiğini, istedikleri zaman din adamıyla görüştüklerini anlattılar. Her pazar ayine katıldıklarını, inancın onları hayatta tuttuğunu söylediler.

Araştırma III

Almanya Konstanz'da "Klinikum Konstanz" Hastanesinde yapılan çalışmalar

Hastanede din adamı olarak çalışan Andreas Kluger ile odasında yapılan görüşme:

27 Ağustos 2006 Konstanz Almanya

"3 kişiyiz. 1 protestan, 2 katolik rahibiz.

Yol bitiminde devreye giriyoruz. Yolda biz yokuz. Sadece hastalarla değil, hasta yakınları ile de görüşüyoruz.

Bana hastalar kendileri müracaat ediyorlar. Bazen de aileleri başvuruyorlar. Bazı zamanlar da hemşireler şu hastaya git iyi olur diyorlar. Beni tanıyan doktorlar da bazı hastalara gitmemi öneriyorlar.

Ağır hastalar kapalı kutu gibidir. Konuşmuyorlar. Yardımcı olamıyorlar. Dostça davranıyorum. Açılmalarını sağlamaya çalışıyorum.”

Andreas Kluger konuşmanın bu anına kadar yaptıklarını anlattı. Bundan sonra soru sormamı isteyen bir şekilde baktı.

Sorularıma başladım.

- Hastalarla konuşurken hangi psikolojik metodları uyguluyor sunuz?

- Metod benim.

- Ben kendi metodumu götürürüm.

- Önce kendimi tanıtıyorum. Kendini açarsa oraya ruhu dinlendirmek için gidiyorum.

- Ruhu dinlendirmek için ne yapiyorsunuz?

- Her buluşma yeni bir maceradır: Bazıları hemen kapıyı gösteriyor. Sizinle konuşmak istemiyorsa sebep buluyor.

- Bazıları ağlıyor, konuşmaya vakit bile olmuyor. $\mathrm{O}$ anda gelişiyor her şey. 
- Bir din adamı olarak hastanede çalışmak için nasıl bir eğitim aldınız? Hristiyan şeratine göre eğitim aldım ve 16 yıl papaz olarak görev yaptım. Hastalarla görüşmek için 3 ay kurs aldım. Kurs şöyleydi: Her gün hastalarla görüşme yapıp hem teoloji hem de psikoloji mezunu bir hocanın yönetiminde o günkü yaşadıklarımızı diğer kursa katılan papazlarla konuşuyorduk. Hocanın önerileri oluyordu. Üç şeyin önemi ortaya çıktı:

1. Hastanın durumu; biz bu konuyu kurstaki arkadaşlarla tartıştık.

2. Oraya gittiğim zaman papaz olarak değil, kendim olarak gidiyorum. Kendimi onun yerine koyuyorum. Aynı acıları paylaşıyorum.

3. Tanrı. Ayrıcalığın Yaratıcındır. Her insanda Yaratandan bir parça var ve her insanı $\mathrm{O}$ yaratmıştır.

- Hastalarla neler paylaşıyorsunuz?

İnsanlara Yaratıcının verdiği şeylerden aktarıyorum:

a. "İnsanız

b. Hastalık var

c. Hastalık insanlığa ait bir yaşantıdır." diyorum.

Benim için insan olmak Tanrı'nın çocukları olmaktır.

Almanya'nın \% 901 Tanrısız yaşıyor. Mesela düzenli olarak kiliseye gitmiyorlar, incili okumuyorlar. Bu insanlar Yaratıcıya karşı önyargılı. Onlara O'ndan bahsetmeden Tanrı'nın kelimelerini aktarabilirsiniz.

Devam etmek istiyorsa devam ediyoruz. Genelde dostluk ortaya çıkarsa devam ediyoruz. Sadece onlar dostluk hissetmiyor, aynı şekilde ben de yaşıyorum.

Bazıları Yaratıcıyı suçlu buluyor.

- Yaratıcıyı suçlu bulanlara ne diyorsun?

Onlara önce Tanrı Tasavvurlarını soruyorum. Onların öyle düşünmesinin çok insancil olduğunu söylüyorum. Düşüncelerinin yanlış olduğunu, Yaratıcının başka olduğunu söylüyorum. Tanrıyı tanıtıyorum. Tek Tanrı' yı tanıtıyorum. Tanrı tasavvuru üzerinde çalışıyorum Kademe kademe Tanrıyı tanıtıyorum. Bizimle Tanrı beraber ilerliyor. tanrı, sen ve ben, üçümüz yolu beraber katediyoruz.

Şimdi ağır bir ameliyat öncesi bir hastaya gideceğim. Bu özel bir durum.

Konuşmanın sonunda ben de kanser hastalarıyla yaptığım çalışmayı anlattım.

Onların hastalıkla baş etmelerine ve tedaviden yeterince yararlanmalarına yönelik manevi ve psikolojik telkin verildiğini söyledim. Affetme çalışmalarından bahsedildi.

İnsanın hastalığıyla baş etmesine ve yaşamasına yönelik bu çalışma Andreas Kluger'in dikkatini çekti. "Biz daha çok yolun sonunda hastayla görüşü- 
yoruz. Siz yaşamaları, sağlıklarına kavuşmaları için çalışıyorsunuz. Hastalığın dini ve milliyeti olmaz. Ben de bu söylediklerinizi düşüneceğim. Türk hastalar kabul ederse sizin söylediklerinizden bahsedeceğim" dedi.

İsviçre, Avusturya ve Almanya' da "hastanelerde din adamlarının görevlerine ve hastalarla iletişimlerine" ilişkin olarak yapılan çalışmalarda özetle şu sonuçlara ulaşılmıştır:

1. Hastanelerde görev yapan din adamlarının kiliseye bağlı olarak çalıştıkları görülmüştür.

2. Hastanelerde görev yapan din adamları çoğunlukla, ölüme yakın olduğu düşünülen hastalarla ve yakınlarıyla görüşmektedirler.

3. Hastalar hastanelerde görev yapan din adamlarıyla randevu alarak görüşmektedirler.

4. Görüşmelerde dua edilmekte, İncil'den bölümler okunmakta ve günah çıkarılmaktadır.

5. Ağır hastalık yaşayan kişilerin tanrı tasavvurları üzerinde çalışılmaktadir.

6. Hastanelerde görev yapan din adamları kişi öldükten sonra yapılması gereken dini görevleri yapmakla da sorumludur.

7. Hastanelerde görev yapan din adamlarının hastalarla görüşme odaları vardır. Bu odalar ya hastane içinde veya hastaneye ek olarak yapılan hastane bahçesinde yapılmış bir binada bulunmaktadır. Görüşme odalarının yakınında Protestan ve Katolik ibadet yerleri mevcuttur. Bu ibadet yerleri 24 saat açıktır.

8. Din adamları hastanelerde görev yapabilmek için teoloji eğitimlerinin yanında değişen sürelerde kurslara katılmaktadırlar. Kurslarda uygulamalı ve teorik yaklaşım söz konusudur. Genellikle din adamları meslekte bir deneyim döneminden sonra hastane görevi için eğitim almaktadırlar.

9. İlahiyat Yüksek Okuluna bağlı Pastoral Enstitüsü çeşitli eğitim programları düzenlemektedir.

10. Avrupa'da din adamlarının hastanelerdeki görevlerinde ruhbanlık niteliklerinin etkili olduğu görülmektedir ve çoğunlukla, ölüme yakın olduğu düşünülen hastalarla ve yakınlarıyla görüşmektedirler.

\section{TÜRKIYE' DE BIR UYGULAMA ÖRNEĞi}

\section{Olay}

Serap Ankara'da yaşamaktadır. 1999 yılında ailesiyle birlikte, bir yakınının düğünü nedeniyle Gölcük' e giderler. Aslında eşi pek gitmekten yana değildir. Ama o israr eder. Deprem gecesi göçük altında kalırlar. Eşi ve kendisi 
aynı odadadır, kızlarıysa yan odada. O gece eşi vefat eder. Kendisi 3 saat sonra ağır yaralı olarak kurtarılır, parmakları kesilir. Kızlarının, annesinin, yeğenlerinin öldüğünü öğrendiğinde hissettiği derin acı nedeniyle psikiyatrik yardım almaya başlar. Aynı zamanda manevi bir arayış içine girer, yaşadıklarını anlamaya ve anlamlandırmaya ihtiyaç duyar.

\section{Süreç}

Serapla bir konferans sırasında karşılaşıldı. Soruları oldukça fazlaydı. Eşinin ve çocuklarının nereye gittiğini merak ediyordu. Onları düğüne gitmeye zorladığı için kendisini sürekli suçluyordu. Ağlama krizleri vardı. Evine giremiyordu. Çocuklarının eşyalarına dokunamıyordu. Bu arada çocukları vefat ettiği için eşiyle ortak olan mal varlığı, yasal olarak eşinin ailesine kalmıştı. Maddi açıdan zorlanıyordu. Eşinin ailesi "oğlumuz sen istediğin için Gölcük' e gitti. Onun ölümünden sorumlusun" diyorlardı. Bu durum Serap' in kendisini suçlamasını pekiştiriyordu.

Serapla düzenli görüşmelere başlandı. Önce içindeki gücün farkına varması ve yaşadıklarını kabullenmesi için, "Allah kimseye kaldıramayacağı yükü yüklemez" ${ }^{5}$ anlamındaki ayetler söylendi. Ölümün sadece ayrılık olduğu, ruhların hep varolduğu, İslam inancına göre, yakınlarımızla öldükten sonra görüşebileceğimiz anlayışı paylaşıldı. O bu acısıyla baş edip, güzel işler yaparsa onlarla bir araya geldiğinde bu başarılarını paylaşabileceği söylendi. "Bir araya geldiğinizde onlara ne yaptığını anlatmak istersin" diyerek yaşama tekrar bağlanması için telkinler verildi. Yapmak istediği işler konusunda cesaretlendirildi, yardım edildi.

Serap çocuklarının öbür alemde ne yaptığını, yalnız mı olduklarını merak ediyordu. Sürekli sorular soruyordu. Bu konuda Kur'an-1 Kerim' in zamanın göreceli olduğu konusunda sunduğu şu yaklaşım paylaşıldı; bu dünyanın bin yılı ya da ellibin yılı öbür dünyanın bir gününü karşılamaktadır. ${ }^{6}$ Dolayısıyla dünyada zaman daha hızlı akmaktadır. Çocuklarına ve eşine göre kısa zaman içinde, Serap güzel bir hayat yaşadıktan sonra onlarla buluşabilecekti.

Serap'ın intihar girişimleri de olmuştu. Bir defasında Serap telefonla arad. Artık dayanamadığını çocuklarını çok özlediğini ölmek istediğini söyledi. Bu girişimlerinden vazgeçmesi için ona, şöyle bir bakış açısı sunuldu: "Bizim acı çeken, özleyen yanımız ruhumuzdur. Ve ruhumuzun ölmek gibi bir özelliği yoktur. Bizim ölen yanımız bedenimizdir. Biz öldüğümüzde ac1-

4 Individual and His Religion

5 Bakara/ 286. 
larımızı ruhumuzla birlikte taşırız. Bu dünyada acılarımızla baş edip, kendimizi güzelliklere açtığımızda ve normal akışı ile öbür aleme geçtiğimizde daha iyi seviyelerde buluruz kendimizi. Dünyada yaşadığımız ve yaşattığımız bütün güzel işler için kendimizi huzurlu hissederiz. Mevlana ölüm gününü sevgiliye kavuşma günü şeb-i aruz olarak isimlendirmektedir. O da hayatında, zorlu dönemler yaşamıştır. "Hamdım, piştim ve yandım" ifadesiyle yaşadıklarını bir öğrenme ve olgunlaşma süreci olarak anlamlandırmıştır. " Bu açıklamayla Serap ikna olmuştu. Bir daha böyle bir girişimde bulunmadi.

Serap şu anda hayatla barışık. Türk Sanat müziği korosunda çalışmalara katılıyor. Hep gerçekleştirmek istediği bu yeteneği üzerinde çalışıyor. Resim ve çini kurslarına gidiyor.

Serapla 2005 yılı Ramazan ayında umreye gittik. Serap' in oradaki duyguları şöyleydi: "Depremden sonra yaklaşık 3 yıl "Bunu neden başıma verdin diye Yaradanıma sitem etmiştim. Ama şimdi, bana bu acıyla baş edebilme, yeteneklerimi yaşama fırsatı verdiği için şükran duygularıyla, Onun evim dediği yere geldim.”

Serap geldiği noktada kendini şöyle ifade ediyor: "Kabullenmeyi öğrendim. Yaşadığımız olayların tesadüf olmadığını anladım. Yaradanım benim bununla baş edebileceğimi bildiği ve içimdeki gücü çıkarmam için beni bu dünyada bıraktı. Hayatta zorlu olaylarla karşılaşanlara şunları söylüyorum: Ne kadar erken kabul edersen o kadar acılarla kolay baş edebiliyorsun. Şu anda şükürle dopdoluyum. Ödülleri de yaşıyorum. Yaradanım kazancımı o kadar bereketlendirdi ki maddi ve manevi bolluk içindeyim."

Serap'ın hikayesi manevi bir bakış açısıyla yaşadıklarının anlamlandırılmasına, kendisine ve yaşama dair bakış açısını olumlu bir şekilde tekrar şekillendirmesine yardımcı olmuştur. Bu açıdan bu olay pastoral danışma örneğidir.

\section{Sonuç ve Öneriler}

Psikolojik iyileşmenin gerçekleşmesi, ${ }^{7}$ terapistin danışanının dünya görüşünü anlama kapasitesine bağlıdır. Bu etkileşimde terapistin danışanıyla empatik bir iletişime geçmesi, danışanının yaşadığı olayın anlamlandırılmasına yardımcı olur. Pastoral danışma, yaşadıklarımızı anlamlandırmamızda psikolojik danışmanın yanı sıra manevi değerlerden güç alır. Çünkü pastoral danışma, yaşananların üst bir bakış açısıyla değerlendirilmesidir.

6 Mearic/4.; Hac/47; Secde/5.ayetler. Ayrıca bkz. Beyza Bilgin, Ellibin Yıllık Bir Gün, Ankara,1996. 
Bu konuda Vicky Genia, ${ }^{8}$ Seküler Psikologlar Ve Dindar Danışanlar: Profesyonel Düşünceler ve Tavsiyeler başlıklı makalesinde, geleneksel psikoterapinin, çoğunlukla dindar danışanların ihtiyaçlarını karşılama konusunda yetersiz olduğunu belirtmektedir. Seküler psikoterapi, geleneksel ve temel psikolojinin teorik formülasyonundan ortaya çıkmış olan terapötik bir yaklaşıma dayanır. Seküler psikoterapistler, geleneksel danışmanlık ve klinik psikoloji programlarında eğitim almış olup, ruhsal rahatsızlıkların tedavisinde strese karşı koyabilmek için psikodinamik, danışan -merkezli ve davranışsal yönelimli yöntemleri kullanmaktadırlar. Diğer taraftan geleneksel, seküler psikoterapinin teori ve pratikleri dini değerlere açıkça zıt/düşmanca bir tavır geliştirmediklerinde bile ${ }^{9}$ birçok bölümü ile dini boyutu dışta bırakmaktadır. ${ }^{10}$ Bir çok terapist dini bakış açısına yönelik olarak duyarlı görünmekte fakat, dini konularda danışanlarını yönlendirme konusunda kendilerini yeterli hissetmemektedirler. ${ }^{11}$ Bu güven eksikliğinin, bazı seküler terapistlerin, ön hazırlıkla ilgili sınırlı bilgiye sahip olmalarından kaynaklandığını belirtir.

Bu nedenle seküler psikoterapistler kendi toplumlarındaki dini danışma kaynaklarına aşina olabilirler ve din uzmanlarıyla ilişki içerisinde bulunabilirler. Psikoterapistler danışanı ihtiyaç duyduğunda, dini bir danışmana yönlendirebilirler. Zihin sağlıkçıları ve din uzmanları işbirliği yapabilirler. Bu işbirliği, her iki taraftaki uzmanların kendi sınırlılıklarını kabul etmesiyle gerçekleşebilir. Ayrıca psikoterapistlerin eğitim programına dindar bireylerin ruhsal yapılarında dinin rolünü anlamaya yönelik kavramsal bir çerçeve sunmak için "Din Psikolojisi” dersi konabilir.

7 Terapotik bir iletişimin gerçekleşmesi.

8 Vicky Genia, "Secular Psychoterapist and Religious Clients: Professional Considerations and Religious Consideretions", Journal of Counceling \&Development, March/April 1994 Volume 72.

9 Bkz. A. Ellis (1980). "Psychotherapy and atheistic values: A response to A. E. Bergin's "Psychotherapy and religious values", Journal of Consulting and Clinical Psychology, 48, 635-639. Bkz. Freud, S. (1927). The future of an illusion. New York: Doubleday.

10 Bkz. A. Bergin (1980). "Psychotherapy and religious values", Journal of Consulting and Clinical Psychology, 48, 95-105. Bkz. R. Lovinger (1984). Working with religious issues in therapy. New York: Jason Aronson.

11 Bkz. J. Holden, R. Watts, W. Brookshire (1991). "Beliefs of professional counselors and clergy about depressive religious ideation". Counseling and Values, 35, 93-103. Bkz. E. Shafranske \& H. Malony (1990a). "Clinical psychologists' religious and spiritual orientations and their practice of psychotherapy", Psychotherapy, 27, 72-78. E. Shafranske \& H. Malony (1990b). "California psychologists' religiosity and psychotherapy", Journal of Religion and Health, 29,219-231. M. Spero (Ed.). (1985), Psychotherapy of the religious patient. Springfield, IL: Charles C. Thomas. E. M. Stern, (Ed.). (1985). Psychotherapy and the religiously committed patient. New York: Haworth Press. E. Worthington (1986). "Religious counseling: A review of published empirical research", Journal of Counseling and Development, 64, 421 -431. E. Worthington, (1988). "Understanding the values of religious clients: A model and itsapplication to counseling", Journal of Counseling Psychology, 35, 166-174. 
Günümüzde din psikolojisi eğitiminde danışmanlıkla ilgili bilgilere ve deneyime yoğunlaşmak önem taşımaktadır. Ülkemizde hastanelerde ölüm sonrası hizmetler için din görevlileri çalışmaktadır. Bu hizmetin yanı sıra hastanelerde din psikolojisi uzmanları görev yapabilirler. İslam dininde ruhbanlık olmadığı için, ülkemizde gerçekleştirilecek hastane çalışmalarında, hastanede çalışacak kişilerin dini ve psikolojik yaklaşımı bütünleştirmesi önemlidir. Yaşam sürecinde hastalıkla baş edebilmek veya tedavi sürecini huzurlu geçirebilmek için İslam dininin hayata ve insana bakış açısının kültürümüzün manevi değerleriyle bütünleştirilerek hastalara sunulması önemlidir. Günümüzde sağlık konusunda holistik yaklaşımlar önemsenmektedir. Beden- akıl- ruh bütünlüğü teolojik yapının olduğu kadar sağlık sektörünün de önde gelen düşünce biçimidir. İslam Dininin ve Türk kültürünün yaşamaya ve yaşatmaya ilişkin değerlerinden danışmanlık sürecinde yararlanılabilir. 